\title{
Molecular characterisation and pathogenicity evaluation of Aeromonas hydrophila strains isolated from cultured tilapia Oreochromis niloticus in Egypt
}

\author{
AHMED MANSOUR, NADIA B. MAHFOUZ*, MONA M. HUSIEN, AMIRA A. E. Z. M. OMER* \\ AND EMAN M. MOUSTAFA* \\ Fish Diseases Research Department, Animal Health Research Institute, Agricultural Research Center, Dokki, Giza, Egypt \\ *Department of Fish Diseases and Management, Faculty of Veterinary Medicine, Kafrelsheikh University, Egypt \\ e-mail:vetmansour86@gmail.com
}

\begin{abstract}
The objectives of the present study were to characterise Aeromonas hydrophila isolated from diseased tilapia Oreochromis niloticus cultured in Kafrelsheikh farms and to evaluate virulence and pathogenecity. About 200 adult fish exhibiting the onset of clinical signs were bacteriologically examined using Aeromonas isolation medium. The isolates were identified by 16S rRNA gene sequence analysis using species specific primers and then tested for ten virulence genes employing specific primers. Experimental challenge studies were also conducted to investigate the pathogenicity of the recovered $A$. hydrophila strains. Thirty five isolates were identified as $A$. hydrophila based on 16S rRNA gene sequence analysis, which were also positive for presence of four virulence genes (aerolysin, lipase, cytotonic heat stable enterotoxin and haemolysin). Results showed that majority of the examined strains carried one or more virulence genes.
\end{abstract}

Keywords: Aeromonas hydrophila, Molecular techniques, Oreochromis niloticus, Virulence genes

\section{Introduction}

Fish provides high quality cheap source of protein especially for the low income communities. Aquaculture is a fast growing animal production sector in Egypt. Intensification and stress of artificial environments results in the emergence of diseases. Aeromonas hydrophila is the most encountered fish pathogen in the freshwater habitats. Aeromonas infections producing septicaemia as well as ulcerative and haemorrhagic lesions in fish, leads to significant mortality in both wild as well as farmed freshwater and marine fish species that impact the economics of the aquaculture sector. Molecular diagnostic techniques provide an effective tool for fish pathogen detection. Aboyadak et al. (2015) used PCR technique to confirm that $A$. hydrophila was the main cause of disease outbreak in tilapia farms in Egypt with an incidence of $75 \%$ in Kafrelsheikh Governorate while Ashraf et al. (2017) studied the prevalence of haemolysin, cytolytic enterotoxin, aerolysin, cytotoxic enterotoxin and cytotonic heat stable enterotoxins in A. hydrophila and A. caviae isolated from Nile tilapia (Oreochromis niloticus) and catfish (Clarias gariepinus) obtained from local markets at Qalubia Governorate. A similar study was performed by Furmanek-Blaszk (2014) to determine the prevalence of five virulence genes viz., aerolysin, haemolysin, elastase, cytolytic heatlabile enterotoxin and polar flagella from A. hydrophila strain isolated from the River Nile. Corresponding studies were recorded from different countries like Yang et al. (2018) who investigated the incidence and virulence features of $A$. hydrophila in grass carp in south China where the isolated strains were positive for aerolysin, elastase, hemolysin and lipase. Another study was conducted by Ruhil Hayati et al. (2015) to verify the presence of virulence genes in A. hydrophila isolated from farmed and wild Oreochromis spp., Oreochromis mossambicus, Scortum barcoo, Puntius gonionotus, Leptobarbus hoevenii, Pangasius pangasius, Anabas testudineus, Clarias gariepinus and Cichlasoma sp., sampled from Selangor, Malaysia concluding that Aeromonas infections revealed presence of different combinations of the virulence genes. Oliveira et al. (2012) studied the presence of aerolysin, hidrolipase, elastase and lipase genes in A. hydrophila isolates obtained from fish of the Sao Francisco River Valley in Brazil. The main objectives of the present study were to identify $A$. hydrophila strains from tilapia farms at Kafrelsheikh Governorate showing onset of Aeromonas septicemia and to screen for ten virulence genes using specific primers. 


\section{Materials and methods}

\section{Sampling and bacteriological examination}

Bacterial isolations were carried out from 200 nos. of O. niloticus showing clinical signs of skin haemorrhages, on tryptic soy agar (TSA) and subcultured until obtaining pure colonies and then tested on Aeromonas isolation medium. All bacterial cultures were incubated at $28^{\circ} \mathrm{C}$ for $24 \mathrm{~h}$. The isolates were tested for biochemical characteristics using API20NE strips (Biomerieux ${ }^{\odot}$, France) and were also identified employing molecular methods by polymerase chain reaction (PCR). The primers used targeted a species-specific region of 16SrDNA(forward 5'-GGCCTTGCGCGATTGTATAT-3' and reverse 5'- GTGGCGGATCATCTTCTCAGA-3'), to identify A. hydrophila (Trakhna et al., 2009).

\section{DNA extraction and PCR amplification}

DNA extraction was done by thermolysis after culturing the bacterial strains on brain heart infusion broth and incubated for $12 \mathrm{~h}$ in shaker incubator. One hundred microlitre of overnight bacterial culture was mixed with $400 \mu \mathrm{l}$ of sterile distilled water, then transferred to heat block for $5 \mathrm{~min}$ at $95^{\circ} \mathrm{C}$; followed by centrifugation at $15000 \mathrm{rpm}$ for $2 \mathrm{~min}$, at $4^{\circ} \mathrm{C}$. The supernatant was used as DNA template which was stored at $-20^{\circ} \mathrm{C}$ for further studies. Amplification of target genes using bacterial cell lysate as the source of template DNA, was performed in a thermal cycler. PCR amplifications were performed in a total volume of $25 \mu \mathrm{l}$, containing $0.125 \mu \mathrm{l}$ ampli Taq gold DNA polymerase $\left(5 \mathrm{U} \mathrm{ml}^{-1}\right) ; 2.5 \mu \mathrm{l} 10 \mathrm{x}$ PCR buffer; $2.5 \mu \mathrm{dNTP}$ mixture; $1 \mu \mathrm{l}$ of each primer (Forward and Reverse) $\left(20\right.$ pmol $\left.\mu \mathrm{l}^{-1}\right)$ and $5 \mu \mathrm{l}$ genomic DNA. Thirty PCR cycles were run under the following conditions; first step of denaturation at $94^{\circ} \mathrm{C}$ for $2 \mathrm{~min}$, followed by 35 cycles of, denaturation at $94^{\circ} \mathrm{C}$ for $30 \mathrm{~s}$, annealing for $30 \mathrm{~s}$ at $55.5^{\circ} \mathrm{C}$ and a final extension step at $72^{\circ} \mathrm{C}$ for $30 \mathrm{~s}$. After the end of the cycles, one final extension step at $72^{\circ} \mathrm{C}$ for $10 \mathrm{~min}$ was added, according to Trakhna et al. (2009) to detect the A. hydrophila specific$16 \mathrm{~S}$ rRNA gene. For the virulence genes examined, PCR conditions were performed under similar conditions according to references mentioned in Table 1.

Sequence analysis of the virulence genes

The positive virulence genes were subjected to DNA sequence analysis and aligned to the published sequences in the GenBank database of the National Center for Biotechnology Information (NCBI). The PCR products of the virulence genes detected were electrophoresed on $1 \%$ SeaKem ${ }^{\circledR}$ LE agarose gel (Lonza). The gel was placed on UV transilluminator; and the band (about $300 \mathrm{mg}$ ) was cut for extraction of DNA using fast gene gel PCR extraction kits according to Yousr et al. (2007).

Table 1. Primers used for detection of $A$. hydrophila virulence genes

\begin{tabular}{|c|c|c|c|}
\hline Gene & $\begin{array}{l}\text { Primers } \\
5, \rightarrow 3\end{array}$ & $\begin{array}{l}\text { Size } \\
\text { (Sequence length) } \\
\text { (bp) }\end{array}$ & References \\
\hline Hidrolipase (Lip) & $\begin{array}{l}\text { F:AACCTGGTTCCGCTCAAGCCGTT } \\
\text { R:TTGCTCGCCTCGGCCCAGCAGCT }\end{array}$ & 65 & Oliveira et al. (2012) \\
\hline Elastase $(a h y B)$ & $\begin{array}{l}\text { F: ACACGGTCAAGGAGATCAAC } \\
\text { R: CGCTGGTGTTGGCCAGCAGG }\end{array}$ & 540 & \\
\hline Lipase (pla/lip) & $\begin{array}{l}\text { F: ATCTTCTCCGACTGGTTCGG } \\
\text { R: CCGTGCCAGGACTGGGTCTT }\end{array}$ & $383-389$ & \\
\hline Aerolysin (aer) & $\begin{array}{l}\text { F: CCTATGGCCTGAGCGAGAAG } \\
\text { R: CCAGTTCCAGTCCCACCACT }\end{array}$ & $431-1987$ & \\
\hline Cytotonic enterotoxin (alt) & $\begin{array}{l}\text { F: TGACCCAGTCCTGG } \\
\text { R: GGTGATCGATCACC }\end{array}$ & 442 & Hu et al. (2012) \\
\hline Cytotoxic enterotoxin (act) & $\begin{array}{l}\text { F: GAGAAGGTGACCACCAAGAACA } \\
\text { R: AACTGACATCGGCCTTGAACTC }\end{array}$ & 232 & \\
\hline Temperature sensitive protease (eprCAI) & $\begin{array}{l}\text { F: GCTCGACGCCCAGCTCACC } \\
\text { R: GGCTCACCGCATTGGATTCG }\end{array}$ & 387 & \\
\hline Serine protease $(A h p)$ & $\begin{array}{l}\text { F: ATTGGATCCCTGCCTA } \\
\text { R: GCTAAGCTTGCATCCG }\end{array}$ & 911 & \\
\hline Haemolysin $(h l y A)$ & $\begin{array}{l}\text { F: GGCCGGTGGCCCGAAGATACGGG } \\
\text { R: GGCGGCGCCGGACGAGACGGGG }\end{array}$ & 392 & \\
\hline Cytotonic heat stable enterotoxin (ast) & $\begin{array}{l}\text { F: TCTCCATGCTTCCCTTCCACT } \\
\text { R: GTGTAGGGATTGAAGAAGCCG }\end{array}$ & 331 & Balsalobre et al. (2009) \\
\hline
\end{tabular}


Median lethal dose $\left(L D_{50}\right)$ of $A$. hydrophila strains in O. niloticus

A total number of 300 apparently healthy $O$. niloticus, were divided into six major groups for six inoculations (four strains containing virulence genes, one strain free from virulence genes and sterile saline solution as negative control), fifty fish per each group. Each group was divided into five subgroups, ten fish per each subgroup. The sixth group inoculated with sterile saline served as control. Twentyfour hour cultures of each A. hydrophila strain (confirmed by PCR amplification), on nutrient agar plates were used for the challenge studies. The colonies were picked and suspended in sterile saline, tenfold serial dilution was done and only the dilutions in the range of $10^{6}-10^{9}$ were used for challenge experiments. Each fish group was intraperitonially injected with $0.5 \mathrm{ml}$ of each bacterial dilution and observed for mortality one week post-inoculation. Freshly dead fish were subjected to histopathological studies. The $\mathrm{LD}_{50}$ of each A. hydrophila strain was calculated according to Reed and Muench (1938).

\section{Histopathological examination}

Tissue samples collected from the liver, kidney and spleen of freshly dead fish from the the challenge studies were fixed in neutral buffered formalin for histopathological investigations. The specimens were dehydrated and embedded in paraffin wax and sectioned at $3 \mu \mathrm{m}$, stained with haematoxylin and eosin (HE) and examined by light microscopy according to Bancroft and Gamble (2007).

\section{Results and discussion}

The fishes examined showed skin hemorrhages on external body surface characteristic of motile Aeromonas septicemia. Thirtyfive isolates of A. hydrophila were collected from diseased tilapia. The bacterial colonies were creamy-white, circular and convex having 2-3 mm in dia on TSA plates. Putative Aeromonas colonies grown on Aeromonas isolation medium with dark green center and light periphery were selected. Biochemical tests showed positive results for O-nitrophenyl-bD-galactopyranoside, arginine dehydrolyase, lysine decarboxylase, citrate utilisation, indole production, gelatinase and Voges Proskauer. Acid was produced from mannitol. Besides, negative results were obtained for ornithine decarboxylase, $\mathrm{H}_{2} \mathrm{~S}$ production, urease and TDA (tryptophan-deaminase activity). No acid production recorded from inositol, sorbitol, rhamnose, saccharose, melibiose, amygdalin and arabinose.

Molecular characterisation revealed that 35 isolates were positive to $16 \mathrm{~S}$ rRNA gene (103 bp) (Fig. 1). Out of the ten virulence genes screened; four genes [(lipase
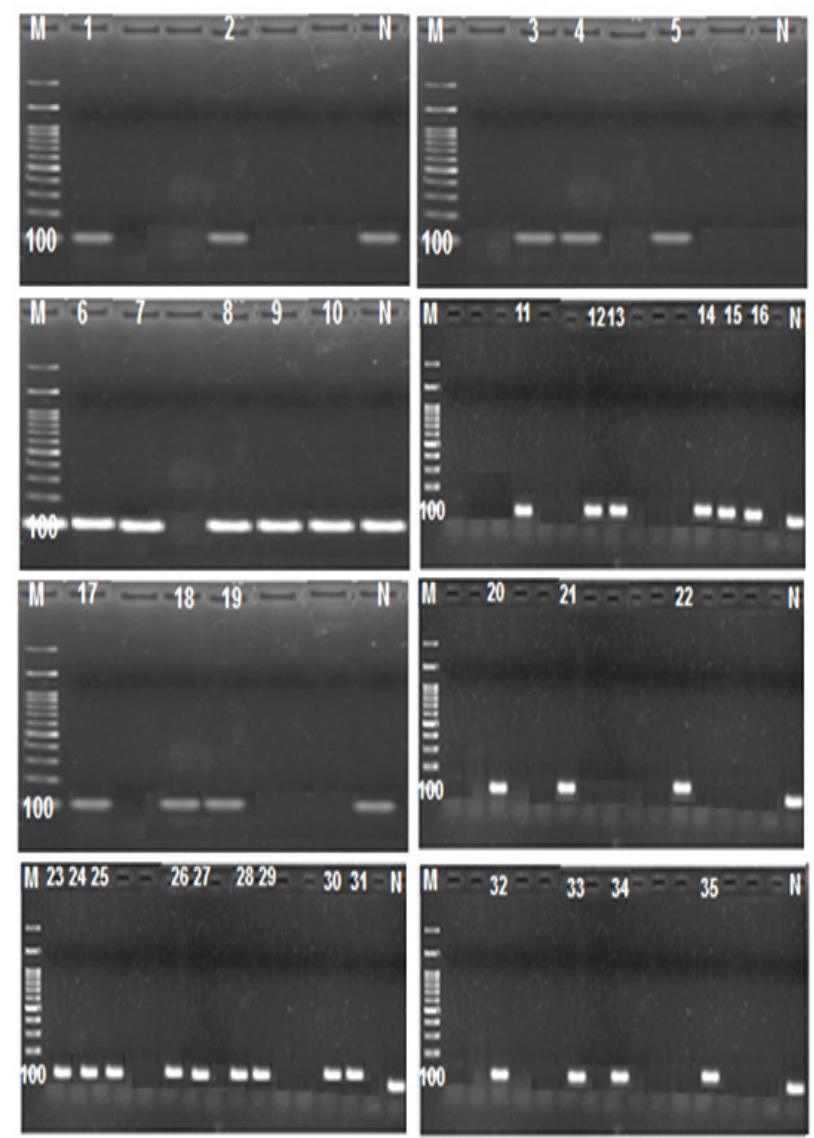

Fig. 1. Electrophoretic pattern of PCR products (103 bp) specific for A. hydrophila in 2\% agarose gel stained with ethidium bromide

Lane M: 100 bp DNA ladder; Lane N: Negative control Lane 1- 35: Positive A. hydrophia

(pla/lip), cytotonic heat stable enterotoxin (ast), aerolysin (aer) and haemolysin $(h l y A)$ ] were found in five isolates with an incidence of $24 \%$ of the strains. Three virulence genes pla/lip, aer and ast were present in seven isolates with an incidence of $33 \%$ of the strains. Two virulence genes pla/lip and aer occurred in six isolates with an incidence of $29 \%$ of the strains and one gene plal lip located in three isolates with an incidence of $14 \%$ of the virulent strains. Incidence of each individual gene was $100 \%$ for lipase (pla/lip), $57 \%$ for cytotonic heat stable enterotoxin (ast), $24 \%$ for aerolysin (aer) and $86 \%$ for haemolysin $(h l y A)$ from 21 strains out of 35 strains of $A$. hydrophila identified, while fourteen strains were free from any virulence genes. The prevalence of A. hydrophila virulence genes were distributed as follows: lipase (pla/lip), the most frequent virulence gene was detected in 21 strains, the cytotonic heat stable enterotoxin (ast) in 12 strains, aerolysin (aer) in 20 strains and 
haemolysin $(h l y A)$ in 5 strains (Fig. 2, 3, 4, 5). Depending on the frequency of the virulence genes in positive A. hydrophila strains, the genotypes carrying virulence genes represented $60.6 \%$, while the genotypes free from virulence genes represented 39.4\% (Table 2, 3).

DNA sequences of the virulence genes were compared with the published sequences in the NCBI GenBank database. Nucleotide sequences of the six virulence genes showed no differences and no mutations. Nucleotide sequence alignment of lipase gene (pla/lip) showed $98 \%$ identity, cytotonic heat stable enterotoxin (ast) showed 98\% identity, aerolysin (aer) showed 98\% identity and haemolysin gene ( hlyA) showed 99\% identity.

The $\mathrm{LD}_{50}$ experiment with strains containing four virulence genes (pla/lip, ast, aer, hlyA) caused 50\% mortality within $12 \mathrm{~h}$ at doses of $1.8 \times 10^{6}$ and $1.6 \times 10^{6} \mathrm{cfu}$, while the other strains having three virulence genes (pla/lip, ast and aer) resulted in $50 \%$ mortality after $18 \mathrm{~h}$ at a dose of $1.5 \times 10^{6} \mathrm{cfu}$. The strains harbouring two virulence genes (pla/lip and aer) caused mortality after $24 \mathrm{~h}$ at dose of $1.2 \times 10^{6} \mathrm{cfu}$ and the strain having only one virulence gene (pla/lip) caused mortality of the fish after $24 \mathrm{~h}$ at
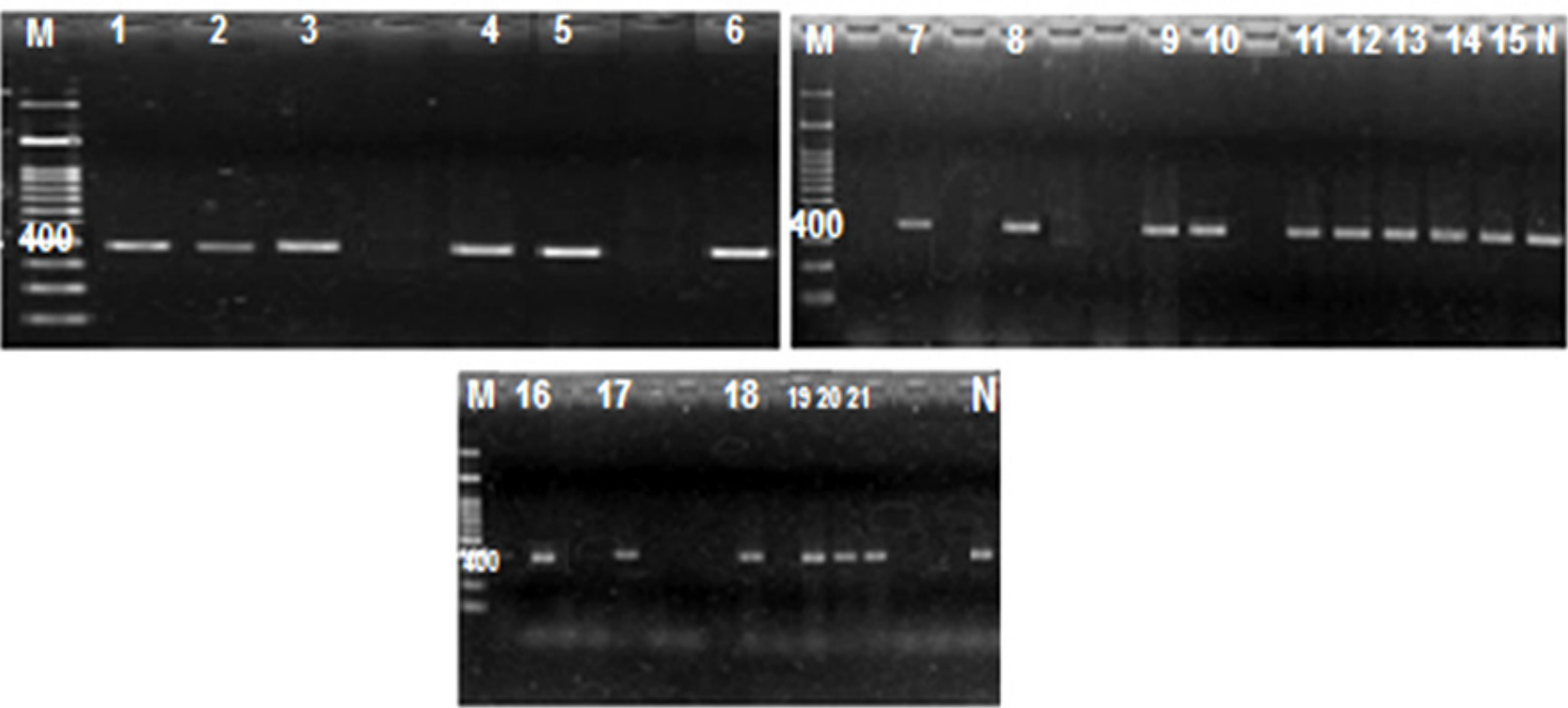

Fig. 2. Ethidium bromide stained agarose gel of PCR products representing amplification of 383-389 bp amplicon of the Lipase (pla/lip) gene in A. hydrophila

Lane M : 100 bp DNA ladder; Lane N : Negative control; Lane 1-21 : Positive pla/lip
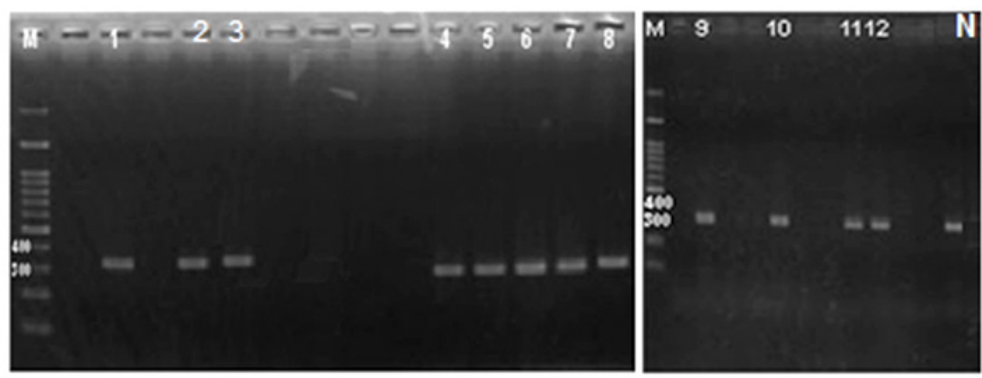

Fig. 3. Ethidium bromide stained agarose gel of PCR products representing amplification of $328 \mathrm{bp}$ amplicon of the cytotonic heat stable enterotoxin (ast) gene in A. hydrophila

Lane M : 100 bp DNA ladder; Lane N : Negative control; Lane 1- 12 : Positive ast 

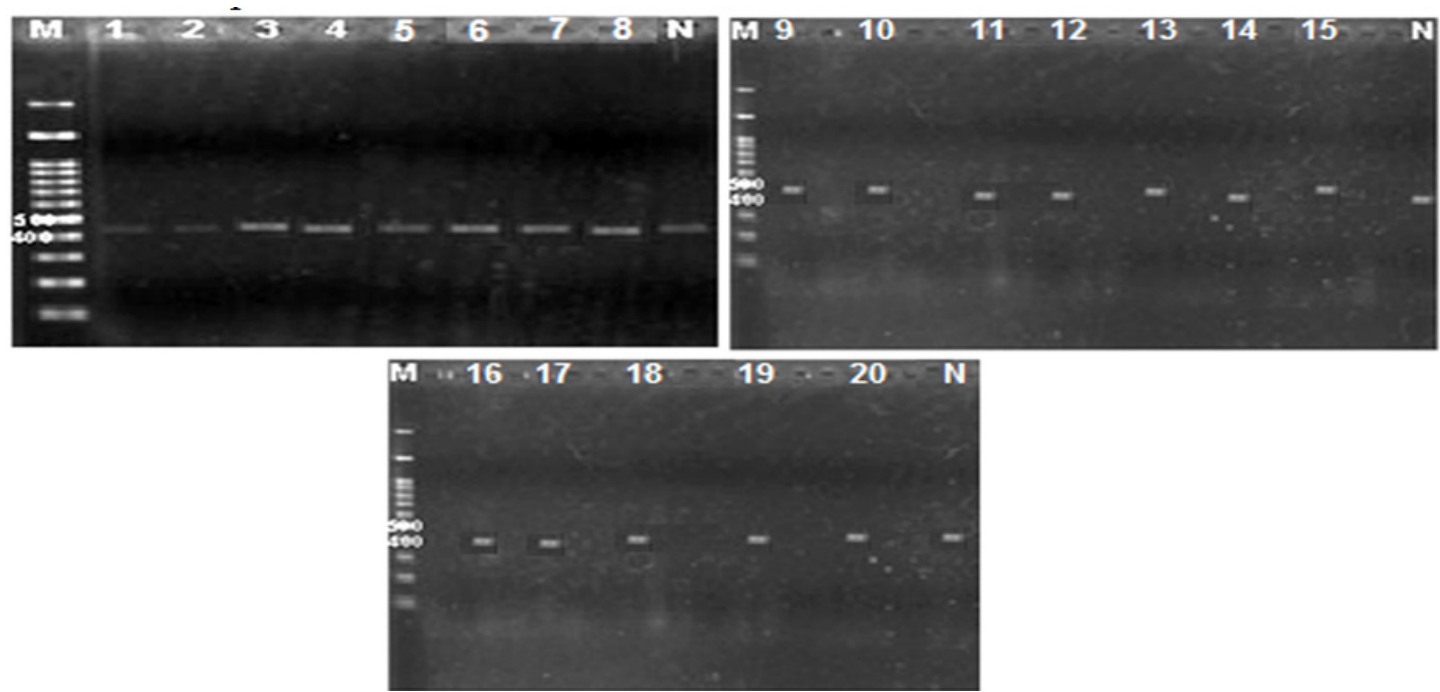

Fig. 4. Ethidium bromide stained agarose gel of PCR products representing amplification of $431 \mathrm{bp}$ amplicon of the Aerolysin (aer) gene in A. hydrophila

Lane M : 100 bp DNA ladder; Lane N : Negative control; Lane 1- 20 : Positive aer

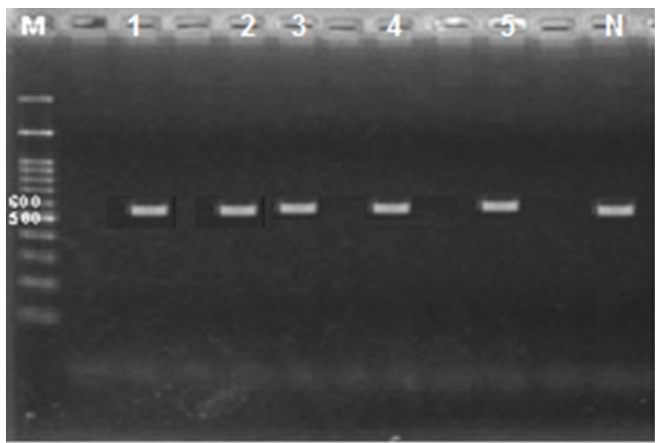

Fig. 5. Ethidium bromide stained agarose gel of PCR products representing amplification of $592 \mathrm{bp}$ amplicon of the haemolysin (hlyA) gene in A. hydrophila

Lane M :100 bp DNA ladder; Lane N : Negative control Lane $1-5$ :Positive hlyA

Table 2. List of virulence genes present in A. hydrophila strains

\begin{tabular}{llll}
\hline Gene & $\begin{array}{l}\text { No. of } \\
\text { isolates }\end{array}$ & $\begin{array}{l}\text { Occurrence } \\
(\%) \text { in isolated } \\
\text { strains }\end{array}$ & $\begin{array}{l}\text { Occurrence } \\
(\%) \text { in virulent } \\
\text { strains }\end{array}$ \\
\hline $\begin{array}{l}\text { Lipase (pla/lip) } \\
\begin{array}{l}\text { Cytotonic heat } \\
\text { stable enterotoxin }\end{array}\end{array}$ & 21 & $60 \%$ & $100 \%$ \\
$\begin{array}{l}\text { (ast) } \\
\text { Haemolysin (hlyA) }\end{array}$ & 5 & $34 \%$ & $57 \%$ \\
Aerolysin (aer) & 18 & $14 \%$ & \\
\hline
\end{tabular}

Table 3. Occurrence and combination of virulence genes in A. hydrophila strains

\begin{tabular}{llll}
\hline Gene & $\begin{array}{l}\text { No. of } \\
\text { isolates }\end{array}$ & $\begin{array}{l}\text { Occurrence } \\
(\%) \text { in } \\
\text { isolated } \\
\text { strains }\end{array}$ & $\begin{array}{l}\text { Occurrence } \\
(\%) \text { in } \\
\text { virulent strains }\end{array}$ \\
\hline $\begin{array}{l}\text { (pla/lip), (ast), } \\
\text { (aer), (hlyA) } \\
\text { (pla/lip), (ast), }\end{array}$ & 5 & $14 \%$ & $24 \%$ \\
$\begin{array}{l}\text { (aer) } \\
\text { (pla/lip), (aer) })\end{array}$ & 6 & $20 \%$ & $33 \%$ \\
(pla/lip) & 3 & $17 \%$ & $29 \%$ \\
\hline
\end{tabular}

cell concentration of $1 \times 10^{6} \mathrm{cfu}$, while the virulence genes negative strain caused $50 \%$ mortality after $36 \mathrm{~h}$ at cell concentrations of $1.8 \times 10^{6} \mathrm{cfu}$. The four strains of A. hydrophila carrying virulence genes, caused mortality of all fish groups within $48 \mathrm{~h}$ at $10^{6} \mathrm{cfu}$ while, the strain free from virulence genes caused mortality of all fish groups at $78 \mathrm{~h}$ at $10^{6} \mathrm{cfu}$. This may be attributed to the presence of other virulence genes, rather than the tested genes, indeed, the variance of the primers used and the pathogen properties as well. Generally the clinical signs of fish infected with virulence genes negative strains were limited to ascites, poor appetite, pale gills and sudden death. The experiments revealed that, the dose $10^{6} \mathrm{cfu}$ caused $50 \%$ mortalities in fish within 12-24 h. Pachanawan et al. (2008) reported $\mathrm{LD}_{50}$ value of $3.4 \times 10^{6} \mathrm{cfu} \mathrm{m}^{-1}$ in $O$. niloticus, for A. hydrophila strains carrying four virulence genes. In contrary, 
Li et al. (2011) reported $\mathrm{LD}_{50}$ at $10^{3}-10^{5} \mathrm{cfu} \mathrm{ml}^{-1}$ and Viji et al. (2011) recorded $\mathrm{LD}_{50}$ at $10^{4}-10^{5} \mathrm{cfu}$ for A. hydrophila in zebra fish and gold fish respectively. The strain free from virulence genes caused $50 \%$ mortalities at a concentration of $1.8 \times 10^{6} \mathrm{cfu}$ in $36 \mathrm{~h}$. The control group showed no mortalities. Haemorrahges on the external body surface may be attributed to the haemolytic effect of the exotoxins; haemolysin ( $\alpha$-haemolysins) and aerolysin ( $\beta$-haemolysins). Both haemolysins induce pore-formation in the cell membrane of the RBCs, leading to haemolysis (Zhang et al., 2000; Singh et al., 2008; Singh et al., 2010; Hidalgo and Figueras, 2013). Lipase, alter the structure of the cytoplasmic membrane of the host tissue cells and help colonisation of $A$. hydrophila on the host tissues causing necrosis (Oliveira et al., 2012), as well as digest the cellular components of the host tissue cells (Zang et al., 2000). The cytotonic heat stable enterotoxin increase the vascular permeability of the gut causing detachment of the intestinal mucosa. Presence of aerolysin in pathogenic A. hydrophila infections may help in diagnosis, prevention and control of the spread of disease and mortalities in aquaculture (Singh et al., 2010; Al-Maleky et al., 2011).

Aboyadak et al. (2015) investigated tilapia farms in Kafrelsheikh governorate and isolated 12 Aeromonas isolates (identified by PCR using Aeromonas sp. primer; amplicon $953 \mathrm{bp}$ ) and confirmed them as $A$. hydrophila using $A$. hydrophila specific $16 \mathrm{~S}$ rRNA gene primer (amplicon $103 \mathrm{bp}$ ) whereas in the current study 35 A. hydrophila strains were identified using $A$. hydrophila specific 16S rRNA primers out of which 21 strains were characterised as carrying one or more virulence genes using specific primers. Ashraf et al. (2017) studied 225 diseased fish samples that included 125 Nile tilapia $(O$. niloticus) and 100 catfish (Clarias gariepinus), collected from different fish markets at Qalubia Governorate for detection of Aeromonas species and associated virulence

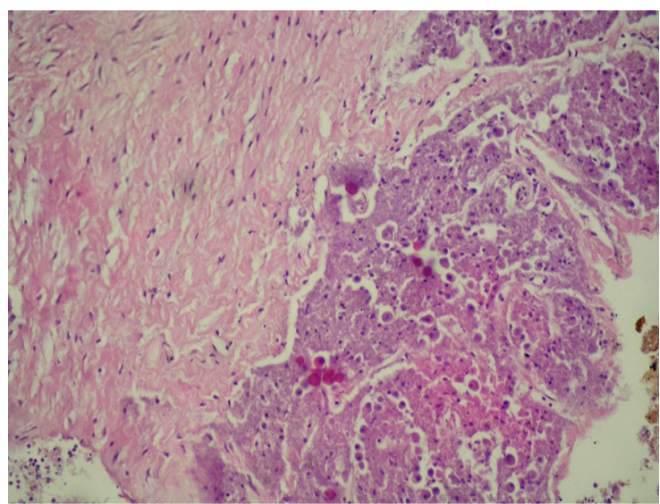

Fig. 6. Photomicrograph of histological section of liver tissue showing coagulative necrosis genes and reported that aerolysin (aer) gene was detected in 9 out of 10 A. hydrophila strains and in 3 out of 6 A. caviae; haemolysin ( hly) gene in 7 out of 10 A. hydrophila and in 2 out of 6 A. caviae; A. hydrophila cytolytic enterotoxin (Ahcytoen) gene in 6 out of 10 A. hydrophila and in 1 out of 6 A. caviae; cytotoxic enterotoxin (act) gene in 6 out of 10 A. hydrophila and in 3 out of 6 A. caviae and cytotonic enterotoxins - heat-stable (ast) gene in 7 out of 10 A. hydrophila and in 3 out of 6 A. caviae strains. In the present study, pla/lip was detected in 21 isolates out of 21 A. hydrophila; ast gene in 12 out of 21 A. hydrophila, aer gene in 18 out of $21 \mathrm{~A}$. hydrophila and hlyA gene in 5 out of 21 A. hydrophila. Ruhil Hayati et al. (2015) tested the presence of 10 virulence genes in A. hydrophila isolated from diseased freshwater fish and reported that all strains contain lip, exu and ser genes whereas none of the strains possessed ela, alt and fla genes. Other genes viz., ast, act, aer and hlyA were present in 30\%, 30\%, $76 \%$ and $95 \%$ of the strains, respectively. In the present study, four virulent genes viz., lipase, cytotonic heat stable enterotoxin, haemolysin and aerolysin were detected out of the ten virulence genes screened. Yang et al. (2018) performed molecular characterisation of $A$. hydrophila from grass carp and their results showed that the incidence of aerolysin, elastase, hemolysin and lipase genes were $71.43,46.03,0.00$ and $55.56 \%$, respectively but in the present study the incidence of the genes was $100 \%$ for lipase, $57 \%$ for cytotonic heat stable enterotoxin, $24 \%$ for hemolysin and $86 \%$ for aerolysin.

Histological sections of the liver tissue showed areas of coagulative necrosis as well as accumulation of melanomacrophages (Fig. 6, 7). The spleen showed lymphoid depletion (Fig. 8), and kidney sections revealed congestion, necrosis, interstitial nephritis and lymphocytic infiltration (Fig. 9).

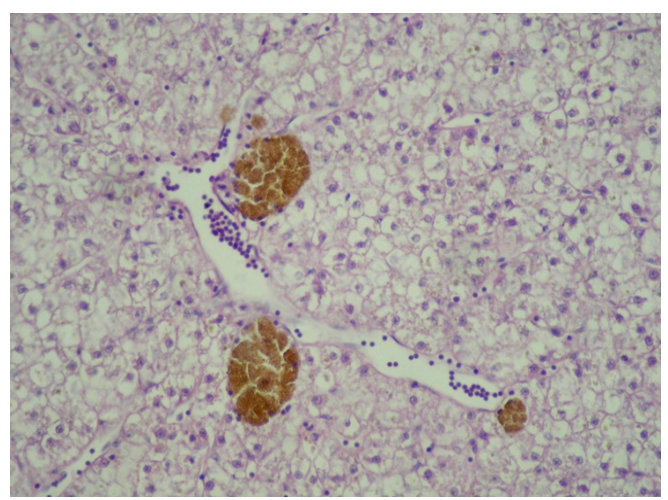

Fig. 7. Histological section of liver showing melanomacrophage centers 


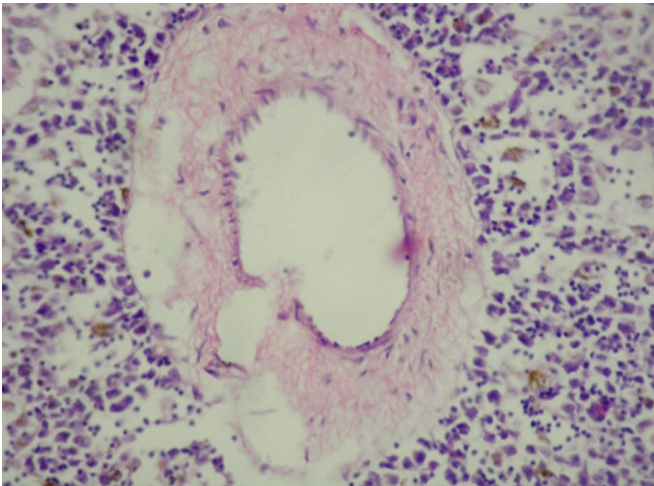

Fig. 8. Photomicrograph section spleen showing lymphoid depletion

\section{References}

Aboyadak, I. M., Nadia, G. M. A., Goda, A. A., Aboelgalagel, W. H. and Alnokrashy, A. 2015. Molecular detection of Aeromonas hydrophila as the main cause of outbreak in tilapia farms in Egypt. J. Aquac. Mar. Biol., 2(5): 00045. DOI: 10.15406/jamb.2015.02.00045.

Al-Maleky, G. M., Karim, R. M. and Al-Abresm, A. N. 2011. Survey of Aeromonas hydrophila in three marine fish species from north-west Arabian Gulf, Iraq. Bas. J. Vet. Res., 10(2): 72-77.

Ashraf, A. Abd, El Tawab, Ahmed, A. A., Maarouf, Fatma, I. El Hofy and Emad, E. A. El Mougy 2017. Detection of some virulence genes in A. hydrophila and A. caviae isolated from freshwater fishes at Qalubia Governorate. Benha Vet. Med. J., 33(2): 489-503.

Balsalobre, L. C., Dropa, M., Matte, G. R. and Matte, M. H. 2009. Molecular detection of enterotoxins in environmental strains of Aeromonas hydrophila and Aeromonas jandaei. J. Water Health, 7(4):685-691.doi.org/10.2166wh.2009.082.

Furmanek-Blaszk, B. 2013. Phenotypic and molecular characteristics of an Aeromonas hydrophila strain isolated from the River Nile. Microbiol. Res., 169 : 547-552.

Trakhna, F., Harf-Monteil, C., AbdelNour, A., Maaroufi, A. and Gadonna-Widehem, P. 2009. Rapid Aeromonas hydrophila identification by TaqMan PCR assay: comparison with a phenotypic method. Lett. Appl. Microbiol., 49: 186-190. doi.org/10.1111/j.1472-765X.2009.02635.x.

Hidalgo, R. B. and Figueras, M. 2013. Aeromonas spp. whole genomes and virulence factors implicated in fish disease. J. Fish Dis., 36: 371-388.

Hu, M., Wang, N., Pan, Z. H., Lu, C. P. and Liu, Y. J. 2012. Identity and virulence properties of Aeromonas isolates from diseased fish, healthy control and water environment

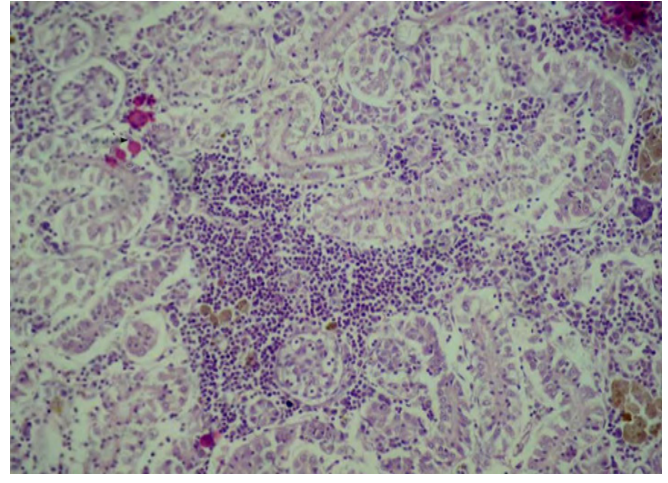

Fig. 9. Histological section of kidney showing congestion, necrosis, interstitial nephritis and lymphocytic infiltration

in China. Lett. Appl. Microbiol., (55): 224-233. doi. org/10.1111/j.1472-765X.2012.03281.x.

Li, L., Ni, X. D., Liu, Y. J. and Lu, C. P. 2011. Detection of three virulence genes alt, ahp and aerA in Aeromonas hydrophila and their relationship with actual virulence to zebra fish. J. Appl. Microbiol., 110: 823-830. doi.org/10.1111/j.13652672.2011.04944.x

Oliveira, S. T. I., Veneroni-Gouveia, G. and Costa, M. M. 2012. Molecular characterization of virulence factors in Aeromonas hydrophila obtained from fish. Pesqui. Vet. Brasil., 32(8): 701-706. doi.org/10.1590/S0100736X2012000800004.

Pachanawan, A., Phumkhachorn, P. and Rattanachaikunsopon, P. 2008. Potential of Psidium guajava supplement fish diets in controlling Aeromonas hydrophila infection in tilapia (Oreochromis niloticus). J. Biosci. Bioeng., 106(5): 419- 424. doi: 10.1263/jbb.106.419.

Ruhil Hayati, H., Hassan, M. D., Ong, B. L., Abdelhadi, Y. M., Nur Hidayahanum, H., Sharifah, R. M., Nora Faten, A. M., Kuttichantran, S. and Milud Alsaid 2015. Virulence genes detection of Aeromonas hydrophila originated from diseased freshwater fishes. Adv. Environ. Biol., 9(22): 22-26.

Singh, V., Rathore, G., Kapoor, D., Mishra, B. N. and Lakra, W. S. 2008. Detection of aerolysin gene in Aeromonas hydrophila isolated from fish and pond water. Indian J. Microbiol., 48: 453-458.

Singh, V., Somvanshi, P., Rathore, G., Kapoor, D. and Mishra, B. N. 2010. Gene cloning, expression and characterisation of recombinant aerolysin from Aeromonas hydrophila. Appl. Biochem. Biotechnol., 160: 1985-1991.

Viji, V. T., Babu, M. M., Velmurugan, S., Kumaran, T., Anand, S. B., Gunasekaran, P. and Citarasu, T. 2011. Virulence factors and molecular cloning of outer membrane protein 
(OMP) gene from virulent Aeromonas hyrophila isolated from infected gold fish Carassius auratus. Bangladesh J. Microbiol., 28(2): 70-75. doi.org/10.3329/bjm.v28i2.11819.

Yang, Y., Miao, P., Li, H., Tan, S., Yu, H. and Yu, H. 2018. Antibiotic susceptibility and molecular characterisation of Aeromonas hydrophila from grass carp. J. Food Saf., 38: e12393. https://doi.org/10.1111/jfs.12393.
Yousr, A. H., Napis, S., Rusul, G. R. A. and Son, R. 2007. Detection of aerolysin and hemolysin genes in Aeromonas spp. Isolated from environmental and shellfish sources by polymerase chain reaction. ASEAN Food J., 14(2): 115-122.

Zhang, Y. L., Ong, C. T. and Leung, K. Y. 2000. Molecular analysis of genetic differences between virulent and avirulent strains of Aeromonas hydrophila isolated from diseased fish. Microbiology, 146: 999-1009. 